\title{
The Impact of the European Convention on Human Rights on Private International Law
}

by

Louwrens R. Kiestra

The focus of the present book is the impact of the European Convention on Human Rights (ECHR) on the three main topics of private international law (PIL): jurisdiction, applicable law, and the recognition and enforcement of foreign judgments.

The author sets off with a discussion whether the ECHR is at all applicable to issues of PIL and the relationship between Article 1 of the Convention and PIL. He then examines the case law of the European Court of Human Rights and selected national courts and by doing so thoroughly maps the interaction between PIL and the rights guaranteed in the ECHR. On this wealth of information the author bases his final conclusions.

Next to a list of cases consulted and a comprehensive bibliography, the book offers brief introductions to PIL and the ECHR for readers who are less familiar with either of the topics. This makes the book not only a valuable tool for specialists and practitioners in the fields covered, but at the same time a well-documented basis for students and starting researchers specializing in either or both directions.

Louwrens Kiestra presently works for the District Court Limburg, The Netherlands.

www.asser.n1/AsserPress/?978-94-6265-031-2

ISBN 978-94-6265-031-2

VI+378 p., hardcover, $€ 129.95$

For ordering information please click: www.springer.com/978-94-6265-031-2

Also available online: link.springer.com/978-94-6265-032-9

Distributed for T.M.C. Asser Press by Springer | springer.com 


\title{
EUROPEAN CONSTITUTIONAL LAW REVIEW
}

20 I 4 Volume io Issue 2

\section{Contents}

\section{Editorial}

For History's Sake. On Costa v. ENEL, André Donner and the Eternal Secret of the Court of Justice's Deliberations 191

Articles

Anne Boerger \& Morten Rasmussen - Transforming European Law: The

Establishment of the Constitutional Discourse from 1950 to 1993199

Sébastien Platon - The 'Equivalent Protection Test': From European Union to United Nations, from Solange II to Solange I (with reference to the Al-Dulimi and Montana Management inc. v. Switzerland Judgment of the European Court of Human Rights) 226

Mattias Wendel - Exceeding Judicial Competence in the Name of Democracy: The German Federal Constitutional Court's OMT Reference 263

Case Notes

Aida Torres Pérez - Melloni in Three Acts: From Dialogue to Monologue 308 Eleni Frantziou - Case C-176/12 Association de Médiation Sociale: Some Reflections on the Horizontal Effect of the Charter and the Reach of Fundamental Employment Rights in the European Union 332

\section{Book Reviews}

Gráinne DE BúrCa \& J.H.H. WeILER (eds.), The Worlds of European Constitutionalism; Matej Avbelj \& Jan Komarex (eds.), Constitutional Pluralism in the European Union and Beyond (Christiaan Timmermans) 349

Agustin Menéndez \& Erik John Fossum, The Constitution's Gift. A Constitutional Theory for a Democratic European Union (Marco Goldoni) 359

Gábor Attila Tóтн (ed.), Constitution for a Disunited Nation: On Hungary's 2011 Fundamental Law (Timothy William Waters) 365

Distributed by:

\section{CAMBRIDGE UNIVERSITY PRESS}

\author{
Cambridge Journals Online \\ journals.cambridge.org
}

